DOI 10.15826/QR.2015.4.136

УДК 811.512.1'367+811.512.157

$+811.512 .132$

\title{
A TRIBUTE TO ELIZAVETA UBRYATOVA: PROFESSIONAL LIFE AND PERSONAL DESTINY
}

In Russia, the name of prominent turkologist Elizaveta Ivanovna Ubryatova, at present is known mostly to specialists who study the languages spoken by the Northern peoples of the country. However, the essence of scientific research of a linguist of such a calibre includes naturally attentive and concerned attitude to the fate of the peoples residing in the North of Russia, which was especially important in the conditions of the Soviet era. Survival of the Northern peoples and their languages became for Ubryatova not only a scientific problem but also a mission of vital importance.

Ubryatova's scientific interests were not restricted to linguistic problems, she also purposefully studied the important monuments of folk literature and ethnography of indigenous peoples. This was due to her scientific breadth, social responsibility, and commitment to a supreme mastery of the research object. That is why she became the founder of the original linguistic and cultural school in the study of the history and structures of languages spoken by peoples living in the North of Russia.

The scale of her bright personality, combined with her intelligence, patience, and feminine care about colleagues and students, made her a center of attraction for researchers in this field. She launched an extensive project of publishing works devoted to folklore of the peoples who inhabited the Northern territories of Russia, and whose traditional culture became a part of the world culture as a result.

The languages of the Dolgans and Yakuts became the main topics of her research. In this article, we outline the major ideas proposed by Ubryatova in her works, viz., those concerning the origin of the Turkic languages, Dolgan and Yakut in particular, and principles of the organization of the Yakut syntax.

In her works, devoted to syntactic problems, Ubryatova determined the fundamental characteristic features of systemic organization of Turkic languages, Yakut in particular, as the ability of these languages to link language units of different levels between each other by using the same grammatical means. In Turkic languages, almost all syntactic relations between clauses can be expressed grammatically, and this linguistic phenomenon entails the existence of a diverse and advanced system of non-finite verbal forms. These important findings can be successfully generalised to embrace all Altaic languages.

Addressing a linguistic problem, Ubryatova combined her deep intuition with intensive field work and systematic theoretic investigation.

Monographs and textbooks written by Ubryatova belong to the gold reserve of Turkology and cultural linguistics. 
Keywords: the Yakut language, the Dolgan language, syntax of simple and complex sentences, the ancient Turkic language, the ancient Uighur language, substrate.

Среди российских лингвистов имя Елизаветы Ивановны Убрятовой известно преимущественно специалистам, изучающим языки народов Севера. Однако суть научных изысканий лингвистов этого профиля закономерно включала в себя неравнодушное отношение к судьбе народов Севера в условиях советского времени, что для Убрятовой было не только научной, но и жизненной задачей. Елизавета Ивановна, путь которой отчасти случайно пересекся с исследованием не только языка, но и памятников фольклорной словесности и этнографии, отнюдь не случайно, а в результате научной добросовестности и стремления к доскональному знанию объекта исследования становится основателем оригинального лингвокультурологического направления в изучении истории и структуры языков народов, живущих на севере России.

Масштаб личности, яркая индивидуальность в сочетании с настоящей интеллигентностью, терпением и женской заботой об окружающих сотрудниках и учениках сделали ее центром притяжения, позволили сформировать школу, запланировать и осуществить величественный проект издания фольклора народов Севера, где самобытная культура этой территории стала частью мировой культуры. Главными в ее исследовании стали тюркские языки - долганский и якутский. В статье прописаны основные тезисы работ Убрятовой по темам «Происхождение тюркских языков» и «Принципы организации синтаксиса якутского языка». В трудах по синтаксису Елизавета Убрятова определяет особенность системной организации тюркских языков, и якутского в частности, как способность единиц разного уровня соединяться при помощи одних и тех же средств. Идея Убрятовой о том, что почти все синтаксические отношения имеют грамматические выражения, что и определяет систему глагольных форм, как показано в статье, оказалась принципиально важна не только для тюркологии. В ее лингвистических изысканиях тонкая интуиция сочеталась с огромной полевой работой и системными исследованиями каждого вопроса. Научные сочинения Убрятовой составляют золотой фонд тюркологии.

Ключевые слова: якутский язык; долганский язык; синтаксис простого и сложного предложения; древний тюркский язык; субстрат; древний уйгурский язык.

Elizaveta Ivanovna Ubryatova was born on October 27, 1907 into the family of a state employee. After graduating from the Irkutsk State University she worked for three years in the Upper-Bulayskaya School for kolkhoz youth in the Cheremhovskii district of the Irkutsk region. At the time, she wanted to do research in the field of Russian folklore. In 1932 she was offered to go to teach in the North of Russia. 
Of all the proposed options - Chukotka, Kamchatka, Taimyr - she choseTaimyr. About Taimyr Elizaveta Ivanovna knew then still very little but she liked the name of the place. Thus, in the initial national boarding school of the small polar settlement (stanok) Chasovnya (Chapel) of the NorilskPyasinskii Nomadic Council there appeared a new teacher. In the stanok Chasovnya was the kolkhoz named after Red Army, the shop of integrated cooperation, and national boarding school, placed in an old chapel. A standard school building was built in 1932-1934 from local timber. From the diaries, which were kept in turn by the teachers of this school Elizaveta I. Ubryatova and Boris Ivanovich, whose family name the author of this article does not know, it is clear that in those years there was "amateur writing” on the Dolgan language. "The second day of training 1932-1933 academic year: "Boys worked well. They seriously and busily wrote the phrase in the native language (by Russian letters) U bar (water is)," "24 / XI Boris Ivanovich began teaching in the mother tongue. We taught the word $U$ (in Russian 'water')." Boris belonged to the new wave of teachers who went through the workers' school, without having good education before it. So, he knew decimal fractions, but had not even heard of the rational numbers. He first reacted cautiously toward Elizaveta Ivanovna, but later, after he had assessed her knowledge, hard work, and attitude to the students he said approvingly: "Even though you were intellectual, you were a good person."

It was a great pleasure for children to teach their teachers Dolgan language. The pleasure was mutual. In the evenings children gathered in the bedroom telling tales. Their performance was artistic, and the audience vividly responded to all the events described in fairy tales. In the diary of Elizaveta I. she wrote: "Because of Dolgan tales I would like to know the native language." And during her stay in the stanok Chasovnya she started to study Dolgan language hard. She began writing down texts in the language. Fairy tales, songs, riddles. One of the experts in Dolgan language, K. N. Suslov, told her five tales. He was a wonderful storyteller, but very demanding. He told tales for hours, and it was impossible to interrupt him. It was also impossible to get up, and it was very hard to sit for hours on the floor with legs crossed. Tales were written in pencil in school notebooks. Later, written text (about five hundred pages) served as the basis for describing language of the Norilsk Dolgans. One of these folk tales was published in the series "Folklore of Siberia and the Far East." To learn the Dolgan language Ubryatova went to Leningrad, where she became a $\mathrm{PhD}$ student at the Leningrad Institute of the Northern peoples. From 1934 to 1937, she worked under the guidance of one of the greatest scientists of Russia - the member correspondent of the Academy of Sciences of USSR S. E. Malov.

1940, she defended her thesis on the language of the Norilsk Dolgans. Attending her oral PhD defense, N. K. Dmitriev had already noticed that, judging by the thesis, Dolgan - is not a dialect of the Yakut language, but a separate language. So it was approximately at that time when the Dolgan language was recognized as an independent language, and writing in the Dolgan language was created. After the defense Ubryatova joined the staff of 
the Institute of Language and Thought, where she continued to work under the supervision of S. Y. Malov. In 1939, she, along with Sergei Yefimovich, went to Yakutsk to participate in the reform of the Yakut writing system. Elizaveta Ivanovna always remembered with pleasure this trip, but they were met there with suspicion. Yakut intellectuals and scientists had closely followed the process. The proposed reforms aroused strong objections, but Ubryatova was pleased with rigour with which the Yakuts defended their language. They arrived somewhere in the autumn, Elizaveta Ivanovna was wearing rubber boots, and she remembered how cold her legs were when she was stopped on the street by someone from the adherents of the Yakut writing, and someone explained to her why it was necessary to keep the existing Yakut graphics. The Yakut language became the main language which Elizaveta I. studied during her life time. Sometimes, she said: "How lucky I was that I got into the Yakut language." When others pointed out that if she were engaged in a different language, it would be just as interesting, she answered: "No, the Yakut language with its complexity, characteristics of the organization - is the most interesting language."

The studying of the Dolgan language had laid the foundations which led Ubryatova to the Yakut language.

The need to identify the origin of the Dolgan language, and the comparison of it with the Yakut language, made Elizaveta Ubryatova to think of a number of problems associated with the history of formation of not only the Dolgan language, but also Turkic languages in general. The main question which arose was as following: how could the Turkic languages spread in the foreign language environment?

Elizaveta Ivanovna Ubryatova always stressed the importance of the processes of Turkization of foreign-language peoples for understanding the history of Turkic languages. She also proposed that "secondary Turkization," i. e. the phenomenon, when some Turkic language, thanks to the dominant position of its speakers, was often used to win in interaction with related Turkic languages, was of a great importance as well.

The process of Turkization to which the Dolgans were subjected, could be observed by Ubryatova directly. The core of the Dolgan nation had been formed long before their migration to Taimyr. Distinctive features of the Turkic language of this group of Yakut were so significant that Elizaveta Ivanovna dated the beginning of formation of the Dolgan language no later that from the end of the XVI century. B. O. Dolgikh singled out nine ethnic groups which existed among the Dolgans [Долгих]. There were the Dolgans themselves, then the Evenki, Yakuts, the ethnic group of Russian peasants, who came to the Taimyr Peninsula in the 16-17 centuries from Central and Eastern parts of White Sea Coast, and Enets as well. The transition of these groups in the Dolgan language continued during the stay of Ubryatova on the Taimyr Peninsula. In Norilsk-Pyasinskii Nomadic Council there were 2-3 families in which the older generation did not speak the Dolgan language but only their own ones (Evenki, Russian); their children were bilingual, and only the third generation spoke the Dolgan language [Убрятова, 1985a]. 
Shift to another language can be normally viewed as the result of ongoing ethnic process. The language in this case serves as a means of consolidating the results of such an ethno-genetic process. The process of moving people to another language is usually long and complicated. Sometime several neighboring nations can change their language, and then a new language can be developed, with a complex system of dialects or a group of related languages. According to Ubryatova, the linguistic landscape of Uzbekistan, Bashkortostan, and Khakassia can be considered as a good example of such a transition [Убрятова, 19856, с. 45]. However, the spread of the Turkish language in the foreign language environment was not enough to form a new Turkic language or dialect. Ubryatova watched the Dolgan and Yakut cases where even a massive shift in the Yakut and Dolgan languages of foreign language population did not entail the formation of a new dialect.

Among the Dolgans, Elizaveta Ivanovna Ubyratova had the opportunity to see how the representatives of other nationalities (Evenki, Nganasans, Enets) joined the Dolgans, adopted their way of life entirely, and moved to the Dolgan language. If they were children or teenagers, they had not even had an accent. Similar observations were made by Ubryatova among the Evenki, who switched their language to the Yakut language. Transition of some local inhabitants, who were native speakers of other languages, to the Yakut language took place perennially; however, new dialects did not appear.

The impact of language of the substrate on the superstratum manifests itself either in a long massive bilingualism, or in the situation when one or the other language becomes spoken by a whole group of the population at the same time, and what is more this group of people is living in isolation [Убрятова, 1960a, с. 13].

Manifestation of features of the language of the substrate can reveal itself at different language levels. The most "expected" level is lexical. Ubryatova paid great attention to changes in the semantic structure of words in the languages having close interaction, synchronous or diachronic, with the languages of other families.

Changes in the semantics of the Yakut words, which are used by the Dolgans, could occur under the influence of the semantics of the same words in the Evenki language. Ubryatova was considering changes in the meaning of the word sugun 'bilberry' in the Dolgan language. This word had the same meaning in the language of the Norilsk Dolgans; however, in other groups of the Dolgan language this word meant 'berry' in general, and only then 'bilberry'. In the Evenki language the name for bilberry 'dikte' served as the name for berries in general, despite the fact that the verb diktev- means 'to turn blue, and the word dikteme means 'blue, grey-blue.' An even more striking example of the restructuring of semantics of the word in accordance with the Evenki type gives the word emij 'breast.' In the Dolgan language it acquired another meaning, which is 'milk', because in the Evenki language the word ukun meant 'woman's breast,' 'udder', 'breast milk.' The ancestors of the contemporary Dolgans, adopted the Turkic word emij and gave it all the same meanings of the Evenki word [Убрятова, 1966, с. 57-58]. 
Language-substrate can reveal itself in the changing of the trend of the development of any language level: so the apprehended Yakut phonetic system, the Dolgan language "did not understand" the law of the Yakut vowel harmony. The Yakut diphthongs changed into difthongoids in Dolgan, which usually turned into wide or narrow vowels, often having the normal duration. The Yakut vowel harmony is going in accordance with the first component of a diphthong, so after yo the vowel a can occur. Changing the diphthong yo into a wide vowel o, the Dolgan language retained the Yakut sequence of vowels in the vocal chain, but this is a mechanical sequence. It reveals "the erosion of the law of vowel harmony" in Dolgan [Там же, c. 46].

The article by Ubryatova "Some ancient areal phenomena in the languages of the peoples of Siberia" is an excellent analysis of the impact of the substrate on the restructuring of the phonetic system of the Yakut language [Убрятова, 19856, с.18-22].

Ubryatova dealt with different aspects of the history of the Yakut language:

1) comparison of the Yakut forms with similar forms of ancient and modern languages;

2) comparison of any form in various sources of the Yakut language;

3) comparison with unrelated forms;

4) studying the history of the Yakut language in the works by Bohtlingk, Radlov and others.

These studies usually lead to such outcomes as understanding the history of the individual forms and words, the formation of the individual subsystems, as well as the formation of the different systems (phonetics, the system of the verb), and - in the end - the history of the language in general.

The analysis of the form of the possessive pronoun in the Dolgan language and its corresponding forms in Yakut could be taken as a good example of the history of a single word and a single grammatical category. In the Dolgan language there is a form of the possessive pronoun, formed from the combination of the personal pronoun and the word gien 'somebody's possession', 'belonging (to),' which takes at the same time possessive affix: min gienim 'mine,' 'belonging to me.'In the Yakut language there are only the forms kini kiene 'belonging to him' and kiniler kiennere 'belonging to them.' These forms in Yakut are treated as a combination of personal pronouns with the particle kiene, which is used to form the possessive forms of nouns [Петров, с. 126]. Ubryatova identified this form in Yakut as a possessive pronoun, which only remained from the full paradigm, preserved among the Dolgans. She compared the Dolgan min gienim 'my own' with ancient Turkic kentum 1) (I) myself, (you) yourself, (he) himself, etc.; 2) one's, one's own, and Turkish kendi 'self” [Древнетюркский словарь, с. 298]. But for a long time Elizaveta I. could not explain the components -tu-di in the ancient personal-reflexive pronouns. It was especially difficult to explain the form kensi 'self' in the Codex Cumanicus [Grönbech, p. 138]. She suggested that tu, tu, si were not affixes, but could be treated as parts 
of a stem. The correspondence $t \sim s$ is well known in the Turkic languages, and it is also known the loss of one of the components in the combination 'sonorant + obstruent' (cf., for example, kirgh. optur, yak. olor, turkmen. otur 'to sit'). This assumption was confirmed in the Karachai-Balkar language, where the personal-reflexive pronoun 'self" was allocated. It went back to Comana kens-i 'self', that is, it remained the stem kes-u of Comana kens-i with fallen $\mathrm{n}$ [Хабичев, с. 62-65]. In the monument "Exquisite gift to the Turkic language” (turk. Ettühfet-üz-Zekiyye fil-l-lûğat-it-Türkiyye. Geviren Besim Atalay., Istanbul, 1945) the very stems can be found: kand 'self,' kandi 1) 'self;' 2) 'he,' 'she;' kans 'self,' kandi 1) 'self;' 2) 'he,' 'she' [Фaзылов, Зияева, с. 45, 321-322].

Elizaveta Ivanovna Ubryatova showed how the interaction of the ancient Turkic language (similar to the language of Orkhon texts) with other ancient Turkic languages, through a long period of bilingualism with some Mongolian language and as a result of the spread of the language in the Tungus-speaking environment, developed the contemporary Yakut language, with all its peculiar features. Most specialists on the Yakut language were based on the ancient Chinese sources. According to these materials, the ancestors of the Yakuts, the Kurykans, were considered as members of the union of the Tele tribes. That is why these linguists believed that ancient Yakut was closely related to ancient Uighur. Ubryatova proved the closeness of the Yakut language to the language of the Orkhon monuments. In the sphere of phonetics there are: a) the presence of the velar $n$; b) correspondence of $j \sim \tilde{j} \sim n$ in certain words; c) the occurrence of voiceless consonants in affixes after the final vowel of a stem. In the sphere of morphology there are: a) a large differentiation of the parts of speech in comparison with the modern Turkic languages; $b$ ) the structure of pair words with full parallelism of forms of the components, including verbs; c) a special system of methods for strengthening the lexical meaning of words through their repetition in the derivative form - in the Yakut language there are all types of intensifying constructions which are present in the Orkhon monuments; d) the presence of the accusative affix -yn in the personal-possessive declension; e) displacement of the Turkic case system, i. e., disappearance of the genitive, rethinking the locative case into the partitive one. This can be considered as trends of development that had taken place in the language of Orkhon monuments (use of the dative instead of the locative, the locative instead of the ablative, and the inconsistent use of the genitive).

Most clearly the connection between the Orkhon and the Yakut languages can be observed in the system of verbal forms:

1) the participle in -ar -yyr in the Yakut language is part of the paradigm of the present tense, building the forms of the 3rd person, singular and plural;

2) Yakut preserves the affix -max ( $<d r$.-turk. -duq), which is used to create a special mood in order to express the action the commitment of which is a natural consequence of the previous one; in the grammar of the Yakut language this form is called the presumptive mood; 
3) the Yakut language has the form in -byt $(<d r$-turk. mъš) in active use;

4) Yakut preserves the form of the conditional mood in -tar (dr.-turk. -sar), etc.

In the syntax it can be observed that homogeneous parts of the sentence occur in the forms of the same type; the izafet-construction is a special characteristic of the language; the subject in subordinate clauses is characterized by use of the possessive affixes, etc. [Убрятова, 19606, с. 2-5].

The place of the Mongolian and Tungusic elements in Yakut language is defined in accordance with "line of development, which the Yakut language inherited from the ancient Turkic language, its ancestor." The Mongolian influence reveals itself not only in a large number of lexical borrowings. According to estimates of V. I. Rassadin, in Yakut there are identified about 2500 words of Mongolian origin (for comparison: in Tuva - 2200 words, in Altai - 830, in Tofalar - approximately 500, over 400 words are found in Khakass, in Shor - 200, in the languages of Siberian Tatars - 80, and in the language of the Chulym Turks - 40) [Рассадин, с. 91-93].

Interaction with the Mongolian language had led to a number of important transformations in the field of phonetics: 1) restoration of the consonants dj and č in the system; 2) uvular stops had been changed into fricative sounds; 3 ) the auslaut $s$ changed into -t in a number of affixes; 4) Mongolian influenced the formation of the secondary long vowels and diphthongs.

The system of onomatopoeic words, with all kinds of its components, had penetrated from Mongolian into Yakut. The Mongolian loanwords make up a significant portion of verbs, indicating that there had long existed Yakut-Mongolian bilingualism, as the Turks do not normally borrow verbs.

Under the influence of Tungusic languages the following happened:

1) enrichment of the system of stops, which took the symmetrical form;

2) disappearance of the Turkic fricative, with $z, \breve{z}$, s changed into s;

3) change of $s$ into $h$ in the intervocalic position [Убрятова, 19606, p. 77].

In relations of these languages with Yakut Ubryatova identified three stages, which are as follows:

1) The period of forming the Yakut language with all special features of its grammatical structure. This is the period of long coexistence of a certain ancient people who spoke a language similar to the language of the Orkhon monuments, together with some Mongol and Tungus groups.

2) The change of the language of the Mongol and Tungus groups into the Turkic language. At the end of this period two main dialects of the Yakut language had developed, i. e., the one, which retained unstressed o, and the other one, which retained the unstressed a. This was related to the establishment of a new type of vowel harmony (in the language of the Orkhon monuments in the position of non-initial syllables the narrow labial vowels occurred, much more often than in the contemporary Turkic languages).

3) The period of the spread of the Yakut language beyond the AldanLena County between the two rivers, and the formation of new groups in the regions of Vilyui, Olekma, and Kolyma. 
Arguing proximity of the Turkic language, which was the basis of Yakut, to the language of the Orkhon monuments, Ubryatova also identified a number of forms that indicated a prolonged contact of the ancient Yakut language with the language of other ancient Turkic peoples who were ancient Uighurs and ancient Kirghiz.

In most classifications of Turkic languages the phonetic data was used as the basis for their comparisons. Ubryatova believed that the phonetic features were not always reliable evidence of genetic relationships between languages. Morphological features, among them a system of verbal forms, were much more stable.

Special features of the ancient Turkic-Orkhon language are well known from some of the surviving monuments. In Yakut, the basic elements of the language are not isolated, but systemic, and some forms can be only explained from other ancient Turkic languages. In contrast to ancient Turkic, the language of the ancient Uighurs who created the Uighur Khanate, and the language of the ancient Kyrgyz people, had not been reflected in the written texts, as the ancient Uighurs and Kyrgyz peoples wrote in the early stages of their history in the ancient language, which served as 'stepp koine.' The Uighur language is known from the more recent monuments which had been created on a different site that is East Turkestan. However, some Siberian languages, especially Tofalar and Tuvanian, have a number of features that resemble old written Uighur language. Elizaveta Ivanovna suggested that the language of the ancient Uighurs, who formed the Uighur khanate, was similar to the Uighur language of written texts, as traces of the language could be found in the Turkic languages of Southern Siberia "in the small but very specific phenomena that can be attributed to the grammatical structure of the ancient Uighur language" [Убрятова, 1985a, с. 26].

All the problems, with which Ubryatova dealt, had direct access to the central theme that occupied her during her whole life. That was the systemic organization of the Yakut language [Убрятова, 1976]. The statement of the problem had the traditional character of that time, i. e., the syntax of the Yakut language, first simple, then complex sentences.

Ubryatova recalled one conversation with S. E. Malov when she told him that she wanted to do research in Yakut syntax of the complex sentence. He began to laugh: "Well, of course, complex, all write about complex syntax, but what to do with simple." But when she showed him her work, he said, "Yes, you have the right." Regarding the relative simplicity and complexity of constructions that Ubryatova had defined as complex in the Yakut language, in Turkic studies there is still no single opinion. The debate on the status of such constructions had found extensive coverage in the second volume of her book. Whatever name we give them, we cannot but agree with the fact that they denote all the basic syntactic meanings inherent in Russian complex sentences.

The analysis of such sentences that was made by Ubryatova in the Yakut language, showed that for adequately describing them the theoretical apparatus of the syntax of a complex sentence was required [Убрятова, 1976]. 
The theory, elaborated on the basis of the Yakut language, had been further developed on the material of a number of the Altaic and Ural languages in the works of M. I. Cheremisina and her followers.

The fundamental characteristic features of the systemic organization of Turkic languages, and Yakut in particular, is that the units of different language levels are linked by the same grammatical means. The syntactic constructions, simple and complex, are connected in the same way as the individual words in a simple sentence. Therefore, the first volume of Ubryatova's monograph was largely devoted to the analysis of linkage between the words in a sentence. There exist four main kinds of linkage in the Yakut language. These are as follows: government, coordination, juxtaposition, and "izafet." These means of linkage are used: 1) to link parts in a simple sentence; 2) as a means of linkage in complex (compound) sentences; 3) to link components of analytical structures. The main task of describing the syntax is to show how this phenomenon, common for all Turkic languages, works on the level of predicative constructions.

Ubryatova showed that in the Yakut language predicative constructions, connected between themselves by the same grammatical means as the words in a simple sentence, can express a variety of semantic relationships between the two events: temporal, causal, concessive, comparative, etc. She considered that in the Yakut language almost all the syntactic relations can be expressed by grammatical means. This is due to its agglutinative typology. The special structure of verbal forms is associated with this specific feature of the language. This structure reveals itself as the existence of formally opposed finite and non-finite verbal affixes.

Non-finite predicative verbal forms have the predicative power that is the ability to produce attribute to its bearer. However, they take not only affixes expressing their internal relations (coordination in person with a subject, according to the terminology of Ubryatova), but they also contain affix indicators expressing syntactic relationships between different predicative units. Therefore, the analysis of verbal forms, especially participles and converbs, is an important part of the works devoted to this problem. This is exactly the structure of a predicate unit (containing caseparticipial, postposition-participial, converbal, and some other forms) which becomes the basis for further studies in the formal classifications of dependent clauses in Turkic languages. In the Yakut language, subordinate clauses combine with main clauses or their components with the help of one of the four means of grammatical linkage (government, coordination, juxtaposition, or izafet). Therefore, according to these types of linkage, the 3rd Chapter of the first volume of Ubryatova's monograph was composed. In the section devoted to government, Ubryatova introduced the concept of predicative declension of participles, and showed how it differs from the declension of nouns. She studied the case forms of participles and other words in the case forms, acting as dependent predicates, and defined the types of syntactic relationships, expressed by each form. For each participle the paradigm is built individually. The existence of a specific case-participial 
form of a particular participle cannot be automatically transferred to other forms. That is why the paradigm of participial declension, common for all participles, does not exist. This statement, proposed in the work by Ubryatova, formed the basis of the analysis of the polypredicative constructions in various languages of the Altaic language group.

Studies in the Altai, Khakass, Buryat, Evenki, Tuvanian, and other languages conducted by the linguists belonging to the Novosibirsk syntactic school, revealed that the predicative declension is the leading systemforming mechanism of the Altai hypotaxis. In addition to the main synthetic kinds of linkage of clauses in a compound sentence, Ubryatova considered the analytical means of expression of syntactic relationships, distributing them according to prevalence in the language. In the compound sentence they are as follows: 1) the expression of subordination in a compound sentence with the help of postpositions; 2) derivational affixes as a means of linkage; 3 ) conjunctions in a compound sentence.

As accurately as it was in the analysis of case-participial constructions, she revealed the originality of the use of postpositions, which functioned as a means of linkage between the predicative constructions (clauses). Ubryatova found out that not all postpositions could act in this function, and many of them have the narrowed scope of use and semantics, which is only remotely related to their normal meaning. Development of analytical means of linkage between the predicative units is most clearly represented in the complex sentence. In the Yakut language, the coordinative relationships are normally expressed by intonation, ancient conjunctions (da, dagany), case forms of the demonstrative pronoun ol 'that', the combination of it with postpositions and syntactic words, as well as by converbal and participial forms derived from auxiliary variants of the verbs er- 'to be, buol- 'to become,' gyn- 'to do.' The formation of the system of conjunctions is a relatively recent process for the Yakut language. The analysis of texts by A. Y. Uvarovsky, Yakut folklore, and works by the first Yakut writers allowed Ubryatova to trace the development of the conjunctions in the Yakut language. In these sources, some conjunctions (uonna, itienne) did not exist at all, and the case forms of demonstrative pronouns and their combinations with postpositions and syntactic nouns were used to express logical connection between the separate periods of olonkho. Many contemporary conjunctions and conjunctional combinations could not be found in the dictionary by E. K. Pekarskii. All this indicates that the current system of conjunctions has begun to take shape in the Yakut language just recently. Its formation was due to the development needs of the written language.

This peculiarity of works by Elizaveta Ivanovna Ubryatova - the attention not only to the synchronous system of a language, but also to the process of its formation - passes through all of her works. Interest in the ancient Turkic language was determined largely by her teacher, Sergei Yefimovich Malov.

Ubryatova thought that the understanding of organizing the syntax of the Yakut language came to her during an extremely hard time. As it 
happened, Elizaveta Ivanovna survived the year 1941 in Leningrad, after going through the worst months of the siege of Leningrad. However, memories of that time did not cause her only negative emotions. She worked. She translated the works of K. Grönbech, and thought about Yakut syntax. She was sure that she had found the right way to understand the description of its system. She had not even thought that that terrible period of hunger and cold could have a tragic end. She recalled how when she came into the dining room of the Academy of Sciences, where employees sometimes fed, she met an old friend, who, when she saw her, threw her on the chest, wailing: "Elizaveta Ivanovna, dear, just do not die!" Elizaveta Ivanovna was very surprised because she did not think of dying. She worked, and was sure that this work was very much needed, and she would continue to do this. But in 1942, she was taken from Leningrad in a state of severe dystrophy. In the train, one of the conductors addressed her, a young woman, as "Grandma." Emaciated, she looked much older than her years. At first, she was taken to Yelabuga, then she appeared in Alma-Ata, where she immediately began to work. Not having at hand Yakut texts she wrote an interesting article about the Yakut words in the works of Korolenko. She was closely acquainted with Kazakh scientists and friendly relations with them had carried through all her life.

She had a special relationship with S. K. Kenesbayev with whom they were $k \bowtie r d a s, i$. e. people of the same age. After the war she returned to Leningrad, but soon, joining the Institute of Linguistics of the Academy of Sciences of the USSR, she moved to Moscow, where, from 1955 to1960, she was the head of the department of the Turkic languages.

During this period the members of the sector were very active in studying the dialects of Turkic languages. Large conferences took place in Baku, Alma-Ata, Frunze, and Kazan, where scholars discussed problems that Ubryatova had already actively studied, as she believed that the dialect materials were the most important sources for writing the history of the Turkic languages, particularly the history of unwritten languages. At the same time it had been created a collective monograph "The dialects of Turkic languages," the publication of which began only recently.

In 1963, Elizaveta I. Ubryatova on a proposal made by A. P. Okladnikov and V. A. Avrorin, moved to Novosibirsk. Here she published the second book of her monograph "The syntax of a complex sentence." From that time, twenty-five years have passed, but still she is much ahead of her time. The concept of this work had become the basis of research conducted by the syntactic group of the Institute of History, Philology, and Philosophy of the Academy of Sciences of the USSR. Ubryatova said she was deeply grateful to M. I. Cheremisina, who led the study, because Maya Ivanovna read her book so attentively. Studies conducted by the syntactic group of M. I. Cheremisina showed that the ideas of the syntactic organization of the Yakut language can be successfully generalised to embrace almost all Siberian languages: Turkic, Mongolian, Tungusic-Manchu, Finno-Ugric languages, and even Paleoasiatic. 
Ubryatova never considered herself a teacher, but always around her were disciples and followers. Her scientific contacts covered not only the entire Soviet Union. She maintained relationships with a number of foreign scientists. Thus, she corresponded with Anna Maria von Gabin, and G. Dërfer who presented her his books.

But the closest relationship Ubryatova had, of course, with Yakutia. The role of Elizaveta I. Ubryatova in the scientific life of Yakutia requires a separate article. She was a colleague, adviser, friend, member of numerous expeditions. It is even difficult to determine how significant the personality of Elizaveta Ivanovna Ubryatova was. We could tell about her study of ancient Turkic languages, her reading Altai runic monuments, and about her trip to Mongolia to the runic monuments, to her most beloved monument which was the monument of Tonukuk. Her concept of the origin of the Turkic languages of Southern Siberia is outside the scope of this article. Her works, in many ways ahead of her time, still remain a model not only for her students but also for students of her students.

\section{Список литературы}

Долгих Б. О. Происхождение долган // Сибирский этнографический сборник. Т. 5. М. : Изд-во АН СССР, 1963. 233 с.

Древнетюркский словарь. Л. : Наука, 1969. 676 с.

Петров Н. Е. Частицы в якутском языке. Якутск : Якут. книж. изд-во,1978. 298 с.

Рассадин В. И. Монголо-бурятские заимствования в сибирских тюркских языках.

М. : Наука, 1980.114 с.

Убрятова Е. И. Исследования по синтаксису якутского языка : в 2 ч. Новосибирск :

Наука СО, 1976. Ч. 2. Сложное предложение. Кн.1, 2. Кн. 1. 214 с. Кн. 2. 160 с.

Убрятова Е. И. Историческая грамматика якутского языка. Якутск : Изд-во ЯГУ, $19856.60 \mathrm{c}$.

Убрятова Е. И. О языке долган // Языки и фольклор народов Севера. М. ; Л. : Наука, 1966. С. $41-69$.

Убрятова Е. И. Опыт сравнительного изучения фонетических особенностей языка населения некоторых районов якутской АССР. М. : Изд-во АН СССР, 1960а.151 c.

Убрятова Е. И. Язык норильских долган. Новосибирск : Наука, 1985а. 216 с.

Убрятова Е. И. Якутский язык в его отношении к другим тюркским языкам, а также к языкам монгольским и тунгусо-маньчжурским. М. : Изд-во АН СССР, 19606.13 с.

Фазылов Э. И., Зияева М. Т. Изысканный дар тюркскому языку. Ташкент : Фан, 1978. $450 \mathrm{c}$.

Хабичев М. А. Местоимение в карачаево-балкарском языке. Черкесск : Карачаевско-Черкесское книж. изд-во, 1961. 216 с.

Grönbech K. Komanisches Wöhrterbuch. Kopenhagen : Einar Muntfsgaard, 1942. 341 S.

\section{References}

Dolgikh, B. O. (1963). Proishozhdenie dolgan [Origin of the Dolgans]. In Sibirskij e'tnograficheskij sbornik (Vol. 5). 233 p. Moscow, AN SSSR.

Drevnetyurkskij slovar' [Dictionary of the Old Turkic Language]. (1969). 676 p. Leningrad, Nauka. gaard.

Grönbech, K. (1942). Komanisches Wöhrterbuch. 341 S. Kopenhagen, Einar Muntfs-

Fazy'lov, E'. I. \& Ziyaeva, M. T. (1978). Izy'skanny'j dar tyurkskomu yazy'ku [Exquisite Gift for the Turkic Language]. 450 p. Tashkent, Fan. 
Habichev, M. A. (1961). Mestoimenie v karachaevo-balkarskom yazy'ke [The Pronoun in Karachai-Balkar Language]. 216 p. Cherkessk, Karachaevsko-Cherkesskoe knizhnoe izd-vo.

Petrov, N. E. (1978). Chasticy'v yakutskom yazy'ke [The Particles in the Yakut Language]. 298 p. Yakutsk, Yakutskoe knizhnoe izdatel'stvo.

Rassadin, V. I. (1980). Mongolo-buryatskie zaimstvovaniya $v$ sibirskih tyurkskih yazy'kah [Mongolian-Buryat Borrowing in the Siberian Turkic Languages]. 114 p. Moscow, Nauka.

Ubryatova, E. I. (1976). Issledovaniya po sintaksisu yakutskogo yazy'ka [Studies in the Syntax of the Yakut Language]. (Part II. Slozhnoe predlozhenie. Books 1-2). 214 p., 160 p. Novosibirsk, Nauka SO.

Ubryatova, E. I. (1985b). Istoricheskaya grammatika yakutskogo yazy'ka [Historical Grammar of the Yakut Language]. 60 p. Yakutsk, Izd-vo YaGU.

Ubryatova, E. I. (1960a). Opy't sravnitel'nogo izucheniya foneticheskih osobennostej ya$z y^{\prime} k$ a naseleniya nekotory'h rajonov yakutskoj ASSR [The Comparative Study of the Phonetic Features of the Language of the Population in Some Areas of the Yakut ASSR]. 151 p. Moscow, AN SSSR.

Ubryatova, E. I. (1966). O yazy'ke dolgan [About the Language of the Dolgans]. In Ya$z y^{\prime}$ ki i fol'klor narodov Severa (pp. 41-69). Moscow, Leningrad, Nauka.

Ubryatova, E. I. (1985a). Yazy'k noril'skih dolgan [The Language of the Norilsk Dolgans]. 216 p. Novosibirsk, Nauka.

Ubryatova, E. I. (1960b). Yakutskij yazy'k v ego otnoshenii $k$ drugim tyurkskim yazy'kam, a takzhe $k$ yazy'kam mongol'skim i tunguso-man'chzhurskim [The Yakut Language in Its Relation to Other Turkic Languages, as Well as to the Mongolian and Tungus-Manchu Languages]. 13 p. Moscow, AN SSSR.

The article was submitted on 10.06.2015

Translated by Dr. Lilia Gorelova

\author{
Наталья Николаевна \\ Широбокова, \\ профессор, \\ Институт филологии \\ Сибирского отделения \\ Российской академии наук, \\ Новосибирск, Россия \\ shirobokova_nn@mail.ru
}

\author{
Natalya Shirobokova, \\ Professor, \\ Institute of Philology \\ Siberian Branch of Russian \\ Academy of Sciences, \\ Novosibirsk, Russia \\ shirobokova_nn@mail.ru
}

